\title{
Four New ent-Kauranoids from Isodon rubescens var. lushanensis and Data Reassignment of Dayecrystal B
}

\author{
Hai-Bo Zhang, ${ }^{a, b}$ Jian-Xin Pu, ${ }^{*, a}$ Yuan-Yuan Wang, ${ }^{a}$ Fei He, ${ }^{a, b}$ Yong Zhao, ${ }^{a}$ Xiao-Nian Li, ${ }^{a, b}$ \\ Xiao Luo, ${ }^{a, b}$ Wei-Lie XIAO, ${ }^{a}$ Yan Li, ${ }^{a}$ and Han-Dong Sun ${ }^{*, a}$ \\ ${ }^{a}$ State Key Laboratory of Phytochemistry and Plant Resources in West China, Kunming Institute of Botany, Chinese \\ Academy of Sciences; Kunming 650204, China: and ${ }^{b}$ Graduate School of Chinese Academy of Sciences; Beijing 100039, \\ China. Received August 10, 2009; accepted September 17, 2009; published online October 7, 2009
}

Four new 7, 20-epoxy-ent-kauranoids, rubluanins A-D (1-4) and eleven known ones, were isolated from Isodon rubescens var. Iushanensis, and their structures were elucidated by spectroscopic analysis. Compounds 2-14 were evaluated for their cytotoxicity in several human tumor cell lines (U937, Jurkat, HL-60, K562, SGC790, and HepG2). Among the compounds, lasiokaurin (13) showed significant cytotoxic activity of $0.62 \mu_{\mathrm{M}}$ $\left(\mathrm{IC}_{50}\right)$ in $\mathrm{U} 937$ cells.

Key words Isodon rubescens var. lushanensis; ent-kauranoid; cytotoxicity

Isodon rubescens (Helsm.) HARA (Labiatae), a perennial herb of Isodon genus, has been used as an antitumor folk medicine for the treatment of esophageal and cardiac carcinoma in Henan Province, China. ${ }^{1)}$ From Isodon rubescens var. lushanensis, collected in Lushan Prefecture of Henan Province, five 20-nonoxygenated and fifteen 20-oxygenated ent-kaurane diterpenoids were reported previously. ${ }^{2-6)}$ Since the metabolites of some species in Isodon genus often exhibit biodiversity attributed to their different ecological environments, ${ }^{7-11)}$ we reinvestigated Isodon rubescens var. lushanensis indigenous to Luanchuan Prefecture (western area of Lushan Prefecture), Henan Province, with the aim of identifying new diterpenoids with promising antitumor activity. As a result, four new 7,20-epoxy-ent-kauranoids (rubluanins $\mathrm{A}-\mathrm{D}$, 1-4) along with eleven known diterpenoids, dayecrystal B (5), kamebacetal A (6), henryin (7), kamebakaurin (8), oridonin (9), isodonoiol (10), megathyrin A (11), lasiodonin (12), lasiokaurin (13), epinodosin (14), and 7-isopropyl-podocarpinol (15) were obtained. Compounds 2-14 were evaluated for their cytotoxicity in 6 human tumor cell lines (U937, Jurkat, HL-60, K562, SGC790, and HepG2), and lasiokaurin (13) showed significant cytotoxic activity of
$0.62 \mu \mathrm{M}\left(\mathrm{IC}_{50}\right)$ in $\mathrm{U} 937$ cells. Herein, we report the isolation and structure elucidation of these compounds as well as the cytotoxicity evaluation results.

\section{Results and Discussion}

Rubluanin A (1), obtained as a white amorphous powder, showed a quasi-molecular ion peak at $\mathrm{m} / \mathrm{z} 429.2239$ [M+ $\mathrm{Na}^{+}$(Calcd 429.2253) in its high resolution electrospray ionization mass spectrometry (HR-ESI-MS), corresponding to the molecular formula $\mathrm{C}_{23} \mathrm{H}_{34} \mathrm{O}_{6}$. Analyses of its ${ }^{1} \mathrm{H}-{ }^{13} \mathrm{C}$ NMR, and distortionless enhancement by polarization transfer (DEPT)-NMR data (Tables 1,2) provided evidence that $\mathbf{1}$ possessed one exomethylene, one acetyl group, two tertiary methyls, one methoxyl group, five methylenes, eight methines (including one acetal methine and four oxygenated methines), and three quaternary carbons (Tables 1,2). Thirty-two protons were all attached to corresponding carbons in heteronuclear single-quantum coherence (HSQC) spectroscopy. Three structural fragments, a (C-1 to C-3), b (C-6 to C-7), and $\mathbf{c}(\mathrm{C}-9$ to $\mathrm{C}-13)$, were deduced from the ${ }^{1} \mathrm{H}-{ }^{1} \mathrm{H}$ correlation spectroscopy (COSY) as shown in Fig. 1. The above data indicated that $\mathbf{1}$ had a 7,20-epoxy-ent-kau-
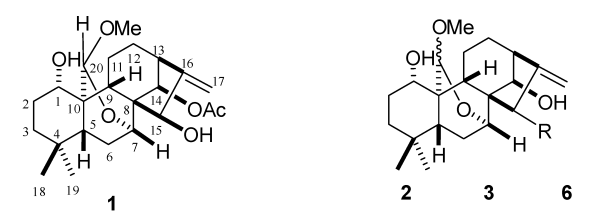

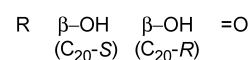
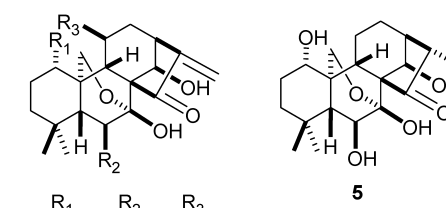

$9 \mathrm{OH} \mathrm{OH} H$

$11 \mathrm{OH} \mathrm{H} \quad \mathrm{H}$

$12 \mathrm{OH} \quad \mathrm{OH} \quad \mathrm{OH}$

$13 \mathrm{OAC}$ OH $\mathrm{H}$

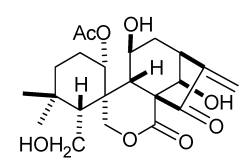

10
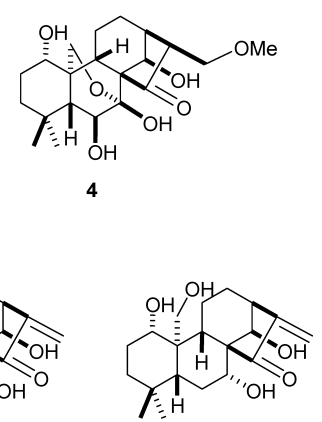

8

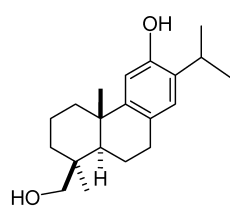

15 
Table 1. ${ }^{1} \mathrm{H}-\mathrm{NMR}$ Data of Compounds $\mathbf{1}-\mathbf{5}$ (Recorded at $\left.500 \mathrm{MHz}\right)$

\begin{tabular}{|c|c|c|c|c|c|}
\hline Position & $\mathbf{1}^{a)}\left(\delta_{\mathrm{H}}\right)$ & $2^{a)}\left(\delta_{\mathrm{H}}\right)$ & $\mathbf{3}^{a)}\left(\delta_{\mathrm{H}}\right)$ & $4^{b)}\left(\delta_{\mathrm{H}}\right)$ & $\mathbf{5}^{b)}\left(\delta_{\mathrm{H}}\right)$ \\
\hline $1 \beta$ & $\begin{array}{l}3.50(1 \mathrm{H}, \mathrm{dd}, 12.0 \text {, } \\
4.8 \mathrm{~Hz})\end{array}$ & $3.50(1 \mathrm{H}, \mathrm{m})$ & $3.44(1 \mathrm{H}, \mathrm{m})$ & $3.65(1 \mathrm{H}, \mathrm{m})$ & $\begin{array}{l}3.63(1 \mathrm{H}, \mathrm{dd}, 11.0, \\
5.5 \mathrm{~Hz})\end{array}$ \\
\hline $2 \alpha$ & $1.61^{c)}(1 \mathrm{H}, \mathrm{m})$ & $1.61^{c)}(1 \mathrm{H}, \mathrm{m})$ & $1.62^{c)}(1 \mathrm{H}, \mathrm{m})$ & $1.84^{c)}(2 \mathrm{H}, \mathrm{m})$ & $1.79(1 \mathrm{H}, \mathrm{m})$ \\
\hline $2 \beta$ & $1.79^{c)}(1 \mathrm{H}, \mathrm{m})$ & $1.79^{c)}(1 \mathrm{H}, \mathrm{m})$ & $1.81^{c)}(1 \mathrm{H}, \mathrm{m})$ & - & $1.86(1 \mathrm{H}, \mathrm{m})$ \\
\hline $3 \alpha$ & $1.48(1 \mathrm{H}, \mathrm{m})$ & $1.48(1 \mathrm{H}, \mathrm{m})$ & $1.43^{c)}(1 \mathrm{H}, \mathrm{m})$ & $1.37^{c)}(1 \mathrm{H}, \mathrm{m})$ & $1.36^{c)}(2 \mathrm{H}, \mathrm{m})$ \\
\hline $3 \beta$ & $1.25(1 \mathrm{H}, \mathrm{m})$ & $1.25(1 \mathrm{H}, \mathrm{m})$ & $1.17^{c)}(1 \mathrm{H}, \mathrm{m})$ & $1.30^{c)}(1 \mathrm{H}, \mathrm{m})$ & - \\
\hline 4 & - & - & - & - & - \\
\hline $5 \beta$ & $1.35^{c)}(1 \mathrm{H}, \mathrm{m})$ & $1.34^{c)}(1 \mathrm{H}, \mathrm{m})$ & $1.54^{c)}(1 \mathrm{H}, \mathrm{m})$ & $1.44(1 \mathrm{H}, \mathrm{d}, 6.3 \mathrm{~Hz})$ & $1.43(1 \mathrm{H}, \mathrm{d}, 7.2 \mathrm{~Hz})$ \\
\hline $6 \alpha$ & $1.60^{c)}(1 \mathrm{H}, \mathrm{m})$ & $1.63^{c)}(1 \mathrm{H}, \mathrm{m})$ & $1.83^{c)}(1 \mathrm{H}, \mathrm{m})$ & $\begin{array}{l}4.19(1 \mathrm{H}, \mathrm{dd}, 11.0, \\
6.5 \mathrm{~Hz})\end{array}$ & $\begin{array}{l}4.24(1 \mathrm{H}, \mathrm{dd}, 10.2, \\
7.4 \mathrm{~Hz})\end{array}$ \\
\hline $6 \beta$ & $\begin{array}{l}2.08(1 \mathrm{H}, \mathrm{t}, 13.5, \\
11.5 \mathrm{~Hz})\end{array}$ & $2.07^{c)}(1 \mathrm{H}, \mathrm{m})$ & $1.94(1 \mathrm{H}, \mathrm{m})$ & - & - \\
\hline 7 & $4.01(1 \mathrm{H}, \mathrm{d}, 3.0 \mathrm{~Hz})$ & $4.15(1 \mathrm{H}, \mathrm{d}, 2.8 \mathrm{~Hz})$ & $4.11(1 \mathrm{H}, \mathrm{t}, 2.7 \mathrm{~Hz})$ & - & - \\
\hline 8 & - & - & - & - & - \\
\hline $9 \beta$ & $1.98(1 \mathrm{H}, \mathrm{m})$ & $1.93(1 \mathrm{H}, \mathrm{m})$ & $1.81^{c)}(1 \mathrm{H}, \mathrm{m})$ & $1.94(1 \mathrm{H}, \mathrm{m})$ & $1.94(1 \mathrm{H}, \mathrm{m})$ \\
\hline 10 & - & - & - & - & - \\
\hline $11 \alpha$ & $2.29(1 \mathrm{H}, \mathrm{m})$ & $2.13^{c)}(1 \mathrm{H}, \mathrm{m})$ & $1.69^{c)}(1 \mathrm{H}, \mathrm{m})$ & $2.50(1 \mathrm{H}, \mathrm{m})$ & $2.38^{c)}(1 \mathrm{H}, \mathrm{m})$ \\
\hline $11 \beta$ & $1.81^{c)}(1 \mathrm{H}, \mathrm{m})$ & $1.75^{c)}(1 \mathrm{H}, \mathrm{m})$ & $1.58^{c)}(1 \mathrm{H}, \mathrm{m})$ & $1.83^{c)}(1 \mathrm{H}, \mathrm{m})$ & $2.05(1 \mathrm{H}, \mathrm{m})$ \\
\hline $12 \alpha$ & $2.42(1 \mathrm{H}, \mathrm{m})$ & $2.33(1 \mathrm{H}, \mathrm{m})$ & $2.36(1 \mathrm{H}, \mathrm{m})$ & $2.01(1 \mathrm{H}, \mathrm{m})$ & $2.38^{c)}(1 \mathrm{H}, \mathrm{m})$ \\
\hline $12 \beta$ & $1.34^{c)}(1 \mathrm{H}, \mathrm{m})$ & $1.32^{c)}(1 \mathrm{H}, \mathrm{m})$ & $1.47^{c)}(1 \mathrm{H}, \mathrm{m})$ & $1.80^{c)}(1 \mathrm{H}, \mathrm{m})$ & $1.60(1 \mathrm{H}, \mathrm{m})$ \\
\hline $13 \alpha$ & $2.66(1 \mathrm{H}, \mathrm{d}, 10.0 \mathrm{~Hz})$ & $2.59(1 \mathrm{H}, \mathrm{d}, 9.9 \mathrm{~Hz})$ & $2.56(1 \mathrm{H}, \mathrm{d}, 9.5 \mathrm{~Hz})$ & $2.88(1 \mathrm{H}, \mathrm{t}, 8.5 \mathrm{~Hz})$ & $2.72(1 \mathrm{H}, \mathrm{d}, 8.3 \mathrm{~Hz})$ \\
\hline $14 \alpha$ & $5.55(1 \mathrm{H}, \mathrm{s})$ & $4.53(1 \mathrm{H}, \mathrm{s})$ & $4.31(1 \mathrm{H}, \mathrm{s})$ & $5.40,(1 \mathrm{H}, \mathrm{s})$ & $5.23(1 \mathrm{H}, \mathrm{s})$ \\
\hline $15 \alpha$ & $4.29(1 \mathrm{H}, \mathrm{s})$ & $4.30(1 \mathrm{H}, \mathrm{s})$ & $4.48(1 \mathrm{H}$, br s $)$ & - & - \\
\hline 16 & - & - & - & $3.72^{c)}(1 \mathrm{H}, \mathrm{m})$ & $2.86(1 \mathrm{H}, \mathrm{t}, 7.0 \mathrm{~Hz})$ \\
\hline 17 & $5.14(2 \mathrm{H}, \mathrm{d}, 10.0 \mathrm{~Hz})$ & $5.18(2 \mathrm{H}$, br s $)$ & $5.20(2 \mathrm{H}$, br s $)$ & $\begin{array}{l}3.83(1 \mathrm{H}, \mathrm{m}) \\
3.77(1 \mathrm{H}, \mathrm{m})\end{array}$ & $3.93(2 \mathrm{H}, \mathrm{d}, 7.0 \mathrm{~Hz})$ \\
\hline 18 & $0.81(3 \mathrm{H}, \mathrm{s})$ & $0.81(3 \mathrm{H}, \mathrm{s})$ & $0.83(3 \mathrm{H}, \mathrm{s})$ & $1.23(3 \mathrm{H}, \mathrm{s})$ & $1.28(3 \mathrm{H}, \mathrm{s})$ \\
\hline 19 & $0.95(3 \mathrm{H}, \mathrm{s})$ & $0.96(3 \mathrm{H}, \mathrm{s})$ & $1.01(3 \mathrm{H}, \mathrm{s})$ & $1.11(3 \mathrm{H}, \mathrm{s})$ & $1.10(3 \mathrm{H}, \mathrm{s})$ \\
\hline 20 & $5.29(1 \mathrm{H}, \mathrm{s})$ & $5.30(1 \mathrm{H}, \mathrm{s})$ & $5.10(1 \mathrm{H}, \mathrm{s})$ & $\begin{array}{l}4.75(1 \mathrm{H}, \mathrm{AB}, 10.1 \mathrm{~Hz}) \\
4.39(1 \mathrm{H}, \mathrm{AB}, 10.1 \mathrm{~Hz})\end{array}$ & $\begin{array}{l}4.74(1 \mathrm{H}, \mathrm{AB}, 10.0 \mathrm{~Hz}) \\
4.35(1 \mathrm{H}, \mathrm{AB}, 10.0 \mathrm{~Hz})\end{array}$ \\
\hline $15-\mathrm{OAc}$ & $2.02(3 \mathrm{H}, \mathrm{s})$ & - & - & - & - \\
\hline 20-OMe & $3.44(3 \mathrm{H}, \mathrm{s})$ & $3.45(3 \mathrm{H}, \mathrm{s})$ & $3.40(3 \mathrm{H}, \mathrm{s})$ & - & - \\
\hline 17-OMe & - & - & - & $3.26(3 \mathrm{H}, \mathrm{s})$ & $3.24(3 \mathrm{H}, \mathrm{s})$ \\
\hline 1-OH & - & $4.35(1 \mathrm{H}, \mathrm{d}, 7.3 \mathrm{~Hz})$ & - & $5.96(1 \mathrm{H}$, br s $)$ & $5.98(1 \mathrm{H}$, br s $)$ \\
\hline 6-OH & - & - & - & $6.55(1 \mathrm{H}, \mathrm{d}, 11.0 \mathrm{~Hz})$ & $6.64(1 \mathrm{H}, \mathrm{d}, 10.5 \mathrm{~Hz})$ \\
\hline 14-OH & - & - & - & $7.75(1 \mathrm{H}$, br s $)$ & $7.14(1 \mathrm{H}, \mathrm{s})$ \\
\hline
\end{tabular}

a) Determined in $\mathrm{CDCl}_{3}$. b) Determined in $\mathrm{C}_{5} \mathrm{D}_{5} \mathrm{~N}$. c) Overlapping signals.

Table 2. ${ }^{13} \mathrm{C}$-NMR Data of Compounds $\mathbf{1}-\mathbf{5}$

\begin{tabular}{|c|c|c|c|c|c|}
\hline Position & $\mathbf{1}^{a)}\left(\delta_{\mathrm{C}}\right)$ & $\mathbf{2}^{b)}\left(\delta_{\mathrm{C}}\right)$ & $\mathbf{3}^{a)}\left(\delta_{\mathrm{C}}\right)$ & $4^{a)}\left(\delta_{\mathrm{C}}\right)$ & $\mathbf{5}^{b)}\left(\delta_{\mathrm{C}}\right)$ \\
\hline 1 & $76.1 \mathrm{~d}$ & $76.3 \mathrm{~d}$ & $75.4 \mathrm{~d}$ & $72.8 \mathrm{~d}$ & $73.3 \mathrm{~d}$ \\
\hline 2 & $30.1 \mathrm{t}$ & $30.2 \mathrm{t}$ & $31.0 \mathrm{t}$ & $30.5 \mathrm{t}$ & $30.5 \mathrm{t}$ \\
\hline 3 & $38.8 \mathrm{t}$ & $39.0 \mathrm{t}$ & $39.5 \mathrm{t}$ & $39.3 \mathrm{t}$ & $39.5 \mathrm{t}$ \\
\hline 4 & $33.7 \mathrm{~s}$ & $33.7 \mathrm{~s}$ & $32.7 \mathrm{~s}$ & $34.1 \mathrm{~s}$ & $34.0 \mathrm{~s}$ \\
\hline 5 & $48.2 \mathrm{~d}$ & $48.3 \mathrm{~d}$ & $47.0 \mathrm{~d}$ & $61.2 \mathrm{~d}$ & $60.1 \mathrm{~d}$ \\
\hline 6 & $26.1 \mathrm{t}$ & $26.3 \mathrm{t}$ & $26.2 \mathrm{t}$ & $74.6 \mathrm{~d}$ & $75.0 \mathrm{~d}$ \\
\hline 7 & $69.3 \mathrm{~d}$ & $69.5 \mathrm{~d}$ & $68.8 \mathrm{~d}$ & $98.1 \mathrm{~s}$ & $98.2 \mathrm{~s}$ \\
\hline 8 & $51.2 \mathrm{~s}$ & $52.2 \mathrm{~s}$ & $53.6 \mathrm{~s}$ & $62.9 \mathrm{~s}$ & $63.7 \mathrm{~s}$ \\
\hline 9 & $44.0 \mathrm{~d}$ & $44.0 \mathrm{~d}$ & $48.0 \mathrm{~d}$ & $53.4 \mathrm{~d}$ & $53.4 \mathrm{~d}$ \\
\hline 10 & $42.7 \mathrm{~s}$ & $42.8 \mathrm{~s}$ & $43.0 \mathrm{~s}$ & $41.5 \mathrm{~s}$ & $41.7 \mathrm{~s}$ \\
\hline 11 & $21.0 \mathrm{t}$ & $21.1 \mathrm{t}$ & $18.1 \mathrm{t}$ & $19.4 \mathrm{t}$ & $20.3 \mathrm{t}$ \\
\hline 12 & $33.2 \mathrm{t}$ & $33.0 \mathrm{t}$ & $33.1 \mathrm{t}$ & $20.6 \mathrm{t}$ & $30.8 \mathrm{t}$ \\
\hline 13 & $42.6 \mathrm{~d}$ & $44.9 \mathrm{~d}$ & $43.6 \mathrm{~d}$ & $37.9 \mathrm{~d}$ & $38.9 \mathrm{~d}$ \\
\hline 14 & $76.5 \mathrm{~d}$ & $73.3 \mathrm{~d}$ & $73.3 \mathrm{~d}$ & $74.3 \mathrm{~d}$ & $75.7 \mathrm{~d}$ \\
\hline 15 & $74.7 \mathrm{~d}$ & $74.3 \mathrm{~d}$ & $73.3 \mathrm{~d}$ & $222.5 \mathrm{~s}$ & $221.7 \mathrm{~s}$ \\
\hline 16 & $161.3 \mathrm{~s}$ & $162.1 \mathrm{~s}$ & $161.3 \mathrm{~s}$ & $52.1 \mathrm{~d}$ & $57.9 \mathrm{~d}$ \\
\hline 17 & $109.1 \mathrm{t}$ & $109.3 \mathrm{t}$ & $109.8 \mathrm{t}$ & $68.9 \mathrm{t}$ & $74.9 \mathrm{t}$ \\
\hline 18 & $32.0 \mathrm{q}$ & $32.0 \mathrm{q}$ & $32.8 \mathrm{q}$ & $33.1 \mathrm{q}$ & $33.5 \mathrm{q}$ \\
\hline 19 & $20.5 \mathrm{q}$ & $20.6 \mathrm{q}$ & $21.4 \mathrm{q}$ & $21.9 \mathrm{q}$ & $22.4 \mathrm{q}$ \\
\hline 20 & $101.8 \mathrm{~d}$ & $102.3 \mathrm{~d}$ & $99.2 \mathrm{~d}$ & $64.1 \mathrm{t}$ & $63.9 \mathrm{t}$ \\
\hline \multirow[t]{2}{*}{$15-\mathrm{OAc}$} & $170.4 \mathrm{~s}$ & - & - & - & - \\
\hline & $21.3 \mathrm{q}$ & - & - & - & - \\
\hline $20-\mathrm{OMe}$ & $55.0 \mathrm{q}$ & $55.1 \mathrm{q}$ & $54.5 \mathrm{q}$ & - & - \\
\hline $17-\mathrm{OMe}$ & - & - & - & $58.7 \mathrm{q}$ & $58.3 \mathrm{q}$ \\
\hline
\end{tabular}

a) Recorded at $100 \mathrm{MHz}$. b) Recorded at $125 \mathrm{MHz}$.

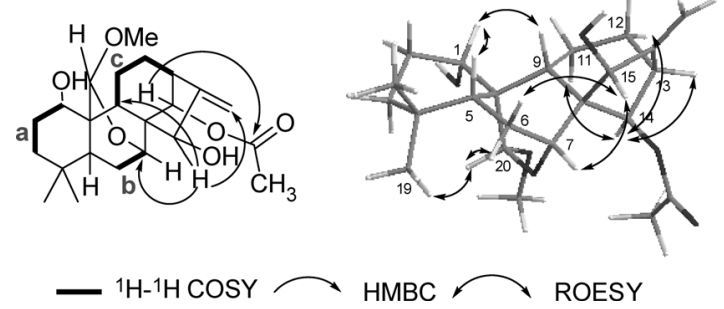

Fig. 1. Key HMBC (from $\mathrm{H}$ to $\mathrm{C}$ ) and ROESY Correlations of $\mathbf{1}$

rane skeleton, partially similar to kamebacetal A (6). ${ }^{12)}$ The conjugated carbonyl group (C-15) of $\mathbf{6}$ was reduced to a secondary hydroxyl in 1, and this assumption was confirmed by the heteronuclear multiple bond coherence (HMBC) correlations from H-15 $\left(\delta_{\mathrm{H}} 4.29\right)$ to $\mathrm{C}-7\left(\delta_{\mathrm{C}} 69.3\right), \mathrm{C}-9\left(\delta_{\mathrm{C}} 44.0\right)$, C$16\left(\delta_{\mathrm{C}} 161.3\right)$, and $\mathrm{C}-17\left(\delta_{\mathrm{C}} 109.1\right)$ as shown in Fig. 1. HMBC correlations from H-14 $\left(\delta_{\mathrm{H}} 5.55\right)$ to a carbonyl carbon $\left(\delta_{\mathrm{C}} 170.4\right)$ indicated that the hydroxyl group at C-14 of 6 was replaced by an OAc group in $\mathbf{1}$. The relative configuration of 1 was revealed by analysis of the rotating frame Overhauser effect spectroscopy (ROESY), in which the correlations of $\mathrm{H}-1$ with $\mathrm{H}-5 \beta$ and $\mathrm{H}-9 \beta$; $\mathrm{H}-14$ with $\mathrm{H}-11 \alpha, \mathrm{H}-12 \alpha$, and $\mathrm{H}-13 \alpha$; and $\mathrm{H}-15$ with $\mathrm{H}-6 \beta, \mathrm{H}-7 \beta$, and $\mathrm{H}-17$ were clearly observed, suggesting that the substituents at C-1, C14 , and $\mathrm{C}-15$ possess $\alpha$-, $\beta$-, and $\beta$-orientations, respectively 
(Fig. 1). Since compound $\mathbf{1}$ is an ent-kauranoid on biogenetic grounds, ${ }^{6}$ the configuration at $\mathrm{C}-20$ was assigned as $S^{*}$ from the ROESY correlations between $\mathrm{H}-20$ and $\mathrm{H}-19, \mathrm{H}-6 \alpha{ }^{13)}$ Consequently, compound 1 was determined to be $\left(20 S^{*}\right)$ $14 \beta$-acetoxy- $\alpha, 15 \beta$-dihydroxy-20-methoxy-7 $\alpha, 20$-epoxyent-kaur-16-ene.

Rubluanin B (2), a white amorphous powder, was shown to possess the molecular formula $\mathrm{C}_{21} \mathrm{H}_{32} \mathrm{O}_{5}$ from the quasimolecular ion peak observed at $m / z$ 387.2154, $[\mathrm{M}+\mathrm{Na}]^{+}$ (Calcd 387.2147) in its HR-ESI-MS. Analyses of the ${ }^{1} \mathrm{H}-$, ${ }^{13} \mathrm{C}$-, and DEPT-NMR spectra suggested that it was also a 7,20-epoxy-ent-kauranoid, bearing a structure similar to kamebacetal A (6). One secondary hydroxyl group was assigned to $\mathrm{C}-15$ in 2 as the HMBC spectrum showed correlations arising from $\mathrm{H}_{2}-17, \mathrm{H}-14 \alpha, \mathrm{H}-13 \alpha$ and $\mathrm{H}-9 \beta$ to $\mathrm{C}-15$. ROESY correlations between $\mathrm{H}-1$ and $\mathrm{H}-5 \beta$, H-9 $\beta$; H-14 and $\mathrm{H}-11 \alpha, \mathrm{H}-13 \alpha$; $\mathrm{H}-15$ and $\mathrm{H}-6 \beta, \mathrm{H}-7 \beta, \mathrm{H}-17$ revealed the relative configuration of the substituents at C-1, C-14, and $\mathrm{C}-15$ possess $\alpha$-, $\beta$-, and $\beta$-orientations, respectively. Compound 2 also displayed ROESY correlations from $\mathrm{H}-20$ to $\mathrm{H}-19, \mathrm{H}-6 \alpha$, and correlations from $\mathrm{H}-14 \alpha$ to $\mathrm{H}-\mathrm{OMe}$ (at $\mathrm{C}-20$ ). These correlations reflected that the configuration at C-20 was $S^{*}$. Therefore, rubluanin B was assigned to be $\left(20 S^{*}\right)-1 \alpha, 14 \beta, 15 \beta$-trihydroxy-20-methoxy-7 $\alpha, 20$-epoxyent-kaur-16-ene.

Rubluanin C (3), an epimer to 2, exhibited a quasi-molecular ion peak at $\mathrm{m} / \mathrm{z} 387.2141[\mathrm{M}+\mathrm{Na}]^{+}$(Calcd 387.2147) in its HR-ESI-MS, in agreement with the molecular formula $\mathrm{C}_{21} \mathrm{H}_{32} \mathrm{O}_{5}$. The only difference between them was the configuration at $\mathrm{C}-20$. The ROESY spectrum of $\mathbf{3}$ showed correlations from $\mathrm{H}-20$ to $\mathrm{H}-11 \alpha, \mathrm{H}-14 \alpha$, and $\mathrm{H}_{3}-\mathrm{OMe}$ (at $\mathrm{C}-20$ ). Therefore the configuration at $\mathrm{C}-20$ of $\mathbf{3}$ was determined as $R^{*}$. Thus, the structure of compound 3 was elucidated as $\left(20 R^{*}\right)-1 \alpha, 14 \beta, 15 \beta$-trihydroxy-20-methoxy-7 $\alpha, 20$-epoxyent-kaur-16-ene.

Rubluanin D (4), isolated as an amorphous white powder, showed a quasi-molecular ion peak at $m / z$ 419.2055 [M+ $\mathrm{Na}^{+}$(Calcd 419.2045) in its HR-ESI-MS, consistent with the molecular formula $\mathrm{C}_{21} \mathrm{H}_{32} \mathrm{O}_{7}$. Analyses of its ${ }^{1} \mathrm{H}-,{ }^{13} \mathrm{C}$-, and DEPT-NMR data (Tables 1,2) suggested that 4 also had a 7,20-epoxy-ent-kaurane skeleton, partially similar to oridonin (9). ${ }^{14)}$ Two structural fragments, a (C-1 to C-3), and b (C-9 to C-14), were deduced from the ${ }^{1} \mathrm{H}-{ }^{1} \mathrm{H}$ COSY spectra as shown in Fig. 2. Comparison of its ${ }^{13} \mathrm{C}-\mathrm{NMR}$ data with those of oridonin revealed that the exomethylene of oridonin disappeared in $\mathbf{4}$, and $\mathbf{4}$ had one more additional methoxyl group. The methoxyl group was assigned to $\mathrm{C}-17\left(\delta_{\mathrm{C}} 68.9\right)$ by the $\mathrm{HMBC}$ correlations arising from $\mathrm{H}_{2}-17\left(\delta_{\mathrm{H}} 3.83\right.$, $3.77)$ to $\mathrm{C}-\mathrm{OMe}\left(\delta_{\mathrm{C}} 58.7\right), \mathrm{C}-13\left(\delta_{\mathrm{C}} 37.9\right), \mathrm{C}-15\left(\delta_{\mathrm{C}} 222.5\right)$, and $\mathrm{C}-16\left(\delta_{\mathrm{C}} 52.1\right)$ (Fig. 2). ROESY correlations between $\mathrm{H}$ 17 and $\mathrm{H}-12 \beta, \mathrm{H}-13 \alpha ; \mathrm{H}-16 \alpha$ and $\mathrm{H}-12 \beta, \mathrm{H}-13 \alpha$ indicated the configuration at C-16 was $S^{*}$. Thus compound 4 was ultimately determined to be $\left(16 S^{*}\right)-1 \alpha, 6 \beta, 7 \beta, 14 \beta$-tetrahydroxy$17 \beta$-methoxy-7 $\alpha, 20$-epoxy-ent-kaur-15-one.

Dayecrystal B (5) was obtained as an epimer to compound 4. The only difference between them was the configuration at $\mathrm{C}$-16. It gave a quasi-molecular ion peak at $\mathrm{m} / \mathrm{z} 419.2049$ $[\mathrm{M}+\mathrm{Na}]^{+}($Calcd 419.2045) in its HR-ESI-MS, corresponding to the molecular formula $\mathrm{C}_{21} \mathrm{H}_{32} \mathrm{O}_{7}$. Dayecrystal $\mathrm{B}$ has been reported previously. ${ }^{15)}$ Here, we prsent the corrections of its data assignment. Compound $\mathbf{5}$ showed ROESY correla-

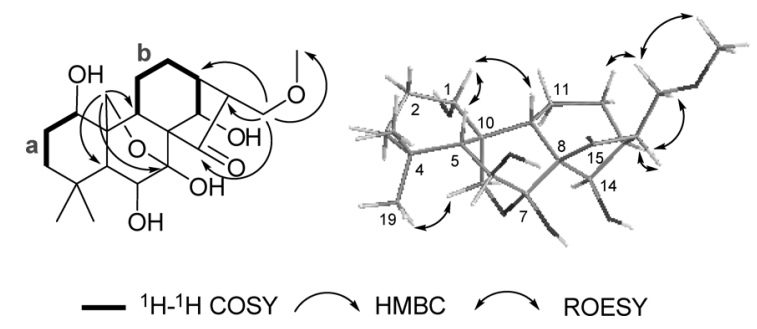

Fig. 2. Key HMBC (from $\mathrm{H}$ to $\mathrm{C}$ ) and ROESY Correlations of $\mathbf{4}$

tions between $\mathrm{H}-16 \beta$ and $\mathrm{H}-12 \beta, \mathrm{H}-9 \beta, \mathrm{H}-13 \alpha$. This means that the configuration at $\mathrm{C}-16$ was $R^{*}$. In the HMBC spectrum, correlations from ${ }^{1} \mathrm{H}$-signals of two methyls $\left(\delta_{\mathrm{H}} 1.3\right.$, $\mathrm{CH}_{3}-18$ and $\left.\delta_{\mathrm{H}} 1.1, \mathrm{CH}_{3}-19\right)$ to one ${ }^{13} \mathrm{C}$-signal $\left(\delta_{\mathrm{C}} 60.1\right)$ of a methine had been found simultaneously. Thus, this methine was assigned to $\mathrm{C}-5$. Then the ${ }^{13} \mathrm{C}$-signal $\left(\delta_{\mathrm{C}} 75.0\right)$ was assigned to C-6 with the help of evidence from the HSQC and ${ }^{1} \mathrm{H}-{ }^{1} \mathrm{H}$ COSY data. Next, in the HMBC spectrum, C-15 $\left(\delta_{\mathrm{C}}\right.$ 221.7) was chosen as a start point. The correlation of $\mathrm{C}-15$ with $\mathrm{H}-14\left(\delta_{\mathrm{H}} 5.23\right)$ was then found. Therefore, the chemical shifts of $\mathrm{C}-14\left(\delta_{\mathrm{C}} 75.7\right)$ and $\mathrm{C}-1\left(\delta_{\mathrm{C}} 73.3\right)$ could be distinguished with the help of evidence from the HSQC data. Thus compound 5 was finally established to be $\left(16 R^{*}\right)$ $1 \alpha, 6 \beta, 7 \beta, 14 \beta$-tetrahydroxy- $17 \alpha$-methoxy- $7 \alpha, 20$-epoxy-entkaur-15-one, and the correction of its data assignment is given in Tables 1 and 2 .

The structures of other known compounds (6-15) were identified to be kamebacetal A (6), ${ }^{12}$ henryin $(7),{ }^{12)}$ kamebakaurin (8), ${ }^{16)}$ oridonin $(9),{ }^{14)}$ isodonoiol (10), ${ }^{17)}$ megathyrin A (11), ${ }^{18)}$ lasiodonin (12), ${ }^{19)}$ lasiokaurin (13), ${ }^{19)}$ epinodosin $(\mathbf{1 4}),{ }^{20)}$ and 7-isopropyl-podocarpinol $(\mathbf{1 5}),{ }^{21)}$ by comparison of their spectroscopic data with those reported in the literature. The results were generally consistent with the constituents reported in the literature, in which fifteen 20oxygenated ent-kauranoids had been isolated from Isodon rubescens var. lushanensis collected in Lushan Prefecture of Henan Province.

Since only a minute amount of compound $\mathbf{1}$ was obtained it could not be tested for cytotoxicity. Compounds 2-14 were tested for their inhibitory effects in the human tumor cell lines (U937, Jurkat, HL-60, K562, SGC790, and HepG2), with 10-hydroxy-camptothecine as the positive control. The results are presented in Table 3. Compounds $\mathbf{2}$ and $\mathbf{3}$ did not show bioactivity while their analogue kamebacetal A exhibited significant inhibitory effects in all of the cell lines, and this result was achieved mainly because the carbonyl groups that conjugated with the exomethylene group in kamebacetal A were replaced by secondary hydroxyl groups in compounds $\mathbf{2}$ and $\mathbf{3}$. For compounds $\mathbf{4}$ and $\mathbf{5}$, in their structures, the cyclopentanone group still remained, but their exomethylene groups were substituted by methoxyls, and then compounds $\mathbf{4}$ and $\mathbf{5}$ just showed weak activity in U937, Jurkat, HL-60, and K562, and they were not cytotoxic in SGC790 and HepG2. The above results further suggest that the cyclopentanone conjugated with an exomethylene group is the active center in ent-kauranoids. ${ }^{22)}$

\section{Experimental}

General Procedures Optical rotations were measured on a PerkinElmer Model 241 polarimeter. UV absorptions were obtained on a Shimadzu UV-2401 PC UV-VIS recording spectrophotometer. IR spectra were deter- 
Table 3. Cytotoxicity Results of Compounds $\mathbf{2 - 1 4}$

\begin{tabular}{ccrcccc}
\hline \hline & \multicolumn{5}{c}{$\mathrm{IC}_{50}(\mu \mathrm{M})$ for cell lines } \\
\cline { 3 - 7 } Compound & U937 & Jurkat & HL-60 & K562 & SGC790 & HepG2 \\
\cline { 2 - 7 } & & & & & \\
\hline \multirow{2}{*}{$\mathbf{n}$} & $>40$ & $>40$ & $>40$ & $>40$ & $>40$ & $>40$ \\
$\mathbf{3}$ & $>40$ & $>40$ & $>40$ & $>40$ & $>40$ & $>40$ \\
$\mathbf{4}$ & 13.57 & 13.65 & 26.69 & 20.41 & $>40$ & $>40$ \\
$\mathbf{5}$ & 14.11 & 14.18 & 34.15 & 26.67 & $>40$ & $>40$ \\
$\mathbf{6}$ & 3.23 & 3.58 & 4.32 & 10.91 & 7.14 & 4.00 \\
$\mathbf{7}$ & 0.72 & 0.93 & 1.16 & 4.74 & 3.09 & 4.05 \\
$\mathbf{8}$ & 1.11 & 2.09 & 3.66 & 5.59 & 7.12 & 12.62 \\
$\mathbf{9}$ & 3.41 & 3.79 & 15.07 & 16.08 & 20 & 19.15 \\
$\mathbf{1 0}$ & 16.25 & 25.27 & $>40$ & 24.94 & $>40$ & $>40$ \\
$\mathbf{1 1}$ & 2.98 & 4.17 & 6.17 & 16.15 & 19.9 & 20.03 \\
$\mathbf{1 2}$ & 18.17 & 25.66 & $>40$ & $>40$ & $>40$ & $>40$ \\
$\mathbf{1 3}$ & 0.62 & 0.63 & 3.16 & 3.02 & 4.01 & 5.57 \\
$\mathbf{1 4}$ & 16.05 & 13.41 & 27.30 & 19.29 & $>40$ & $>40$ \\
Control & 0.105 & 0.03 & 0.036 & 1.6 & 19.80 & 11.90 \\
\hline
\end{tabular}

Positive control: 10-hydroxy-camptothecine.

mined on a Bio-Rad Fts-135 spectrophotometer with $\mathrm{KBr}$ pellets. MS were recorded on a VG Auto spec-3000 spectrometer or Finnigan MAT 90 instrument. One-dimension and 2D-NMR spectra were run on Bruker AV-400 and DRX-500 instruments with TMS as an internal standard.

Plant Material Stems and leaves of Isodon rubescens (HARA) var. lushanensis GAO et Li were collected in Luanchuan Prefecture of Henan Province in June 2007 and air dried. The identity of the plant material was verified by Prof. Xi-Wen $\mathrm{Li}$, and a voucher specimen is deposited in the Herbarium of the Department of Taxonomy, Kunming Institute of Botany, Chinese Academy of Sciences.

Extraction and Isolation The dried and powdered stems and leaves $(4.0 \mathrm{~kg})$ were extracted with $70 \%$ acetone and filtered. After filtration and evaporation of the solvent under vacuum, the residue was suspended in water and partitioned with EtOAc. The EtOAc extract $(117 \mathrm{~g})$ was applied to column chromatography over a silica gel (100-200 mesh, $800 \mathrm{~g})$ column eluted with a system of $\mathrm{CHCl}_{3}$-acetone $(10: 0,9: 1,8: 2,7: 3,2: 1,1: 1)$ to afford fractions A-F. Fraction B ( $28 \mathrm{~g})$ was further chromatographed over MCI gel CHP-20 P (90\% MeOH- $\mathrm{H}_{2} \mathrm{O}$, then $\left.100 \% \mathrm{MeOH}\right)$ to yield fraction $\mathrm{B}_{1}-\mathrm{B}_{3}$. Fraction $\mathrm{B}_{1}$ was further subjected to silica gel eluted with petroleum ether-acetone $(1: 0 \rightarrow 0: 1)$ to afford a mixture of two diterpenoids, then semi-preparative RP18-HPLC $\left(\mathrm{MeOH} / \mathrm{H}_{2} \mathrm{O}, 30: 70,3 \mathrm{ml} / \mathrm{min}\right.$, detector 238 $\mathrm{nm})$ was applied to yield compounds $\mathbf{1 0}(4.1 \mathrm{mg})$ and $7(11.3 \mathrm{mg})$. Fraction C (43 g) was further chromatographed on MCI gel CHP-20 P $(90 \%$ $\mathrm{MeOH}-\mathrm{H}_{2} \mathrm{O}$, then $100 \% \mathrm{MeOH}$ ) to yield fraction $\mathrm{C}_{1}-\mathrm{C}_{4}$, and compound 6 $(437 \mathrm{mg})$ was obtained by recrystallization in $\mathrm{MeOH}$ from the $\mathrm{C}_{1}$ fraction. Fraction $\mathrm{C}_{2}$ was further subjected to a silica gel eluted with petroleum ether-acetone $(10: 1 \rightarrow 0: 1)$ to afford a mixture of two diterpenoids, and then isolated by semi-preparative RP18-HPLC $\left(\mathrm{ACN} / \mathrm{H}_{2} \mathrm{O}, 35: 65,3 \mathrm{ml} / \mathrm{min}\right.$, detector $210 \mathrm{~nm})$ to yield compounds $\mathbf{1}(2.1 \mathrm{mg})$ and $\mathbf{6}$. Compounds $\mathbf{1 3}$ $(7.0 \mathrm{mg})$ and $14(4.8 \mathrm{mg})$ were obtained by recrystallization in $\mathrm{MeOH}$ from the $\mathrm{C}_{3}$ fraction after repeated chromatography over silica gel and RP-18 column $(30-100 \% \mathrm{MeOH})$. Compound $8(5.8 \mathrm{mg})$ was obtained by semipreparative RP18-HPLC (ACN/ $\mathrm{H}_{2} \mathrm{O}, 27: 73,3 \mathrm{ml} / \mathrm{min}$, detector $238 \mathrm{~nm}$ ) from the $\mathrm{C}_{4}$ fraction after repeated chromatography. Compound $\mathbf{1 2}(3.6 \mathrm{mg})$ was also obtained by semi-preparative RP18-HPLC $\left(\mathrm{MeOH} / \mathrm{H}_{2} \mathrm{O}, 30: 70\right.$, $3 \mathrm{ml} / \mathrm{min}$, detector $238 \mathrm{~nm}$ ) from the $\mathrm{C}_{4}$ fraction after repeated chromatography. Fraction D (32 g) was submitted to repeated chromatography including MCI gel, silica gel to afford $\mathrm{D}_{1}-\mathrm{D}_{3}$ fractions. Compounds $2(4.0 \mathrm{mg})$ and 3 $(3.1 \mathrm{mg})$ were isolated from the $\mathrm{D}_{1}$ fraction over a silica gel $(200-300$ mesh, $5 \mathrm{~g})$ column eluted with a system of $\mathrm{CHCl}_{3}-\mathrm{MeOH}(80: 1)$, and then purified by Sephadex-LH 20 gel. Compounds $4(6.2 \mathrm{mg})$ and $5(5.4 \mathrm{mg})$ were also obtained from the $\mathrm{D}_{1}$ fraction after repeated chromatography, and then isolated by semi-preparative RP18-HPLC $\left(\mathrm{MeOH} / \mathrm{H}_{2} \mathrm{O}, 45: 55,3 \mathrm{ml} / \mathrm{min}\right.$, detector $210 \mathrm{~nm})$. Compound $9(7.2 \mathrm{mg})$ was obtained by semi-preparative RP18-HPLC $\left(\mathrm{MeOH} / \mathrm{H}_{2} \mathrm{O}, 45: 55,3 \mathrm{ml} / \mathrm{min}\right.$, detector $\left.238 \mathrm{~nm}\right)$ from the $\mathrm{D}_{2}$ fraction after repeated chromatography. Compound $15(5.7 \mathrm{mg})$ was obtained by semi-prepare RP18-HPLC $\left(\mathrm{MeOH} / \mathrm{H}_{2} \mathrm{O}, 50: 50,3 \mathrm{ml} / \mathrm{min}\right.$, detector $238 \mathrm{~nm}$ ) from the $\mathrm{D}_{3}$ fraction after repeated chromatography.

Rubluanin A (1): White amorphous powder, $[\alpha]_{\mathrm{D}}^{26}+0.00^{\circ}(c=0.064$, $\mathrm{MeOH})$. UV $\lambda_{\max }(\mathrm{MeOH}) \mathrm{nm}(\varepsilon): 205$ (3802). ${ }^{1} \mathrm{H}-$ and ${ }^{13} \mathrm{C}-\mathrm{NMR}\left(\mathrm{CDCl}_{3}\right)$ data: see Tables 1, 2. HR-ESI-MS $[\mathrm{M}+\mathrm{Na}]^{+} \mathrm{m} / z$ : 429.2239 (Calcd for

\section{$\left.\mathrm{C}_{23} \mathrm{H}_{34} \mathrm{O}_{6}, 429.2253\right)$}

Rubluanin B (2): White amorphous powder, $[\alpha]_{\mathrm{D}}^{26}+25.86^{\circ}(c=0.116$, $\mathrm{MeOH}) . \mathrm{UV} \lambda_{\text {max }}(\mathrm{MeOH}) \mathrm{nm}(\varepsilon): 205$ (3090). IR (KBr) $\mathrm{cm}^{-1}: 3431,2930$, 2867, 1657, 1072, 1031. ${ }^{1} \mathrm{H}$ - and ${ }^{13} \mathrm{C}-\mathrm{NMR}\left(\mathrm{CDCl}_{3}\right)$ data: see Tables $1,2$. HR-ESI-MS [M+Na] ${ }^{+} m / z: 387.2154$ (Calcd for $\mathrm{C}_{21} \mathrm{H}_{32} \mathrm{O}_{5}, 387.2147$ ).

Rubluanin C (3): White amorphous powder, $[\alpha]_{\mathrm{D}}^{26}-3.84^{\circ}(c=0.100$, $\mathrm{MeOH})$. UV $\lambda_{\max }(\mathrm{MeOH}) \mathrm{nm}(\varepsilon): 204.2$ (3019). IR $(\mathrm{KBr}) \mathrm{cm}^{-1}: 3432$, 2926, 2857, 1630, 1068, 1031. ${ }^{1} \mathrm{H}-$ and ${ }^{13} \mathrm{C}-\mathrm{NMR}\left(\mathrm{CDCl}_{3}\right)$ data: see Tables 1, 2. HR-ESI-MS [M+Na] ${ }^{+} m / z: 387.2154$ (Calcd for $\mathrm{C}_{21} \mathrm{H}_{32} \mathrm{O}_{5}, 387.2147$ ).

Rubluanin D (4): White amorphous powder, $[\alpha]_{\mathrm{D}}^{27}-5.36^{\circ} \quad(c=0.280$, $\mathrm{MeOH})$. UV $\lambda_{\max }(\mathrm{MeOH}) \mathrm{nm}(\varepsilon): 204.6$ (1479). IR $(\mathrm{KBr}) \mathrm{cm}^{-1}: 3406$, 2942, 1717, 1630, 1455, 1060. ${ }^{1} \mathrm{H}$ - and ${ }^{13} \mathrm{C}-\mathrm{NMR}\left(\mathrm{C}_{5} \mathrm{D}_{5} \mathrm{~N}\right)$ data: see Tables 1, 2. HR-ESI-MS [M+Na] ${ }^{+} m / z: 419.2055$ (Calcd for $\mathrm{C}_{21} \mathrm{H}_{32} \mathrm{O}_{7}, 419.2045$ ).

Dayecrystal B (5): White amorphous powder, $[\alpha]_{\mathrm{D}}^{27}-48.80^{\circ}(c=0.502$, $\mathrm{MeOH}) . \mathrm{UV} \lambda_{\max }(\mathrm{MeOH}) \mathrm{nm}(\varepsilon): 203.4(1349)$. IR $(\mathrm{KBr}) \mathrm{cm}^{-1}: 3397$, 2948, 1716, 1641, 1453, 1060. ${ }^{1} \mathrm{H}$ - and ${ }^{13} \mathrm{C}-\mathrm{NMR}\left(\mathrm{C}_{5} \mathrm{D}_{5} \mathrm{~N}\right)$ data: see Tables 1, 2. HR-ESI-MS [M+Na] ${ }^{+} m / z: 419.2049$ (Calcd for $\mathrm{C}_{21} \mathrm{H}_{32} \mathrm{O}_{7}, 419.2045$ ).

Cytotoxicity Assay The following human tumor cell lines were used: U937, Jurkat, HL-60, K562, SGC790, and HepG2. All the cells were cultured in RPMI-1640 or Dulbecco's modified Eagle's medium (DMEM) (Hyclone, U.S.A.), supplemented with $10 \%$ fetal bovine serum (Hyclone, U.S.A.) at $37^{\circ} \mathrm{C}$ in a humidified atmosphere with $5 \% \mathrm{CO}_{2}$.

Cell viability was assessed by conducting colorimetric measurements of the amount of insoluble formazan that formed in living cells based on the reduction of 3-(4,5-dimethylthiazol-2-yl)-2,5-diphenyltetrazolium bromide (MTT) (Sigma, U.S.A.). ${ }^{23)}$ Briefly, $100 \mu$ l of adherent cells were seeded into each well of 96-well cell culture plates and allowed to adhere for $12 \mathrm{~h}$ before drug addition, while suspended cells were seeded just before drug addition, both with an initial density of $1 \times 10^{5}$ cells $/ \mathrm{ml}$ in $100 \mu \mathrm{l}$ of medium. Each tumor cell line was exposed to the tested compound at various concentrations in triplicate for $48 \mathrm{~h}$, with 10-hydroxy-camptothecine (Sigma, U.S.A.) as positive control. After the incubation, MTT $(100 \mu \mathrm{g})$ was added to each well, and the incubation continued for $4 \mathrm{~h}$ at $37^{\circ} \mathrm{C}$. The cells were lysed with $100 \mu \mathrm{l}$ of $20 \%$ SDS- $50 \%$ DMF after removal of $100 \mu \mathrm{l}$ of medium. The optical density of the lysate was measured at $595 \mathrm{~nm}$ in a 96-well microtiter plate reader (Bio-Rad 680, U.S.A.). The $\mathrm{IC}_{50}$ value of each compound was calculated by the Reed and Muench method. ${ }^{24)}$

Acknowledgements This work was supported financially by the NSFC (Nos. 30772637 to H.-D. Sun and 30830119 to S.-J. Chen), the NSFC-Joint Foundation of Yunnan Province (No. U0832602 to H.-D. Sun), the Major State Basic Research Development Program of China (No. 2009CB522300 and 2009CB940900), the Natural Science Foundation of Yunnan Province (No. 2008CD162), and the Key Project of Knowledge Innovation Project of CAS (KSCX2-YW-R-25).

\section{References}

1) Sun H. D., Xu Y. L., Jiang B., "Diterpenoids from Isodon Species," Science Press, Beijing, 2001, p. 5.

2) Qin C. Q., Liu C. J., Li J. C., An X. Z., Sun H. D., Lin Z. W., Acta Bot. Yunnanica, 6, 333-334 (1984).

3) Li J. C., Liu C. J., Sun H. D., Lin Z. W., Acta Bot. Yunnanica, 8, 93 95 (1986)

4) Qin C. Q., Li F. Q., Li H. L., Sun H. D., Lin Z. W., Acta Bot. Yunnanica, 8, 99-101 (1986).

5) Li J. C., Sun H. D., Lin Z. W., Acta Bot. Yunnanica, 9, 485-486 (1987).

6) Han Q. B., Li M. L., Li S. H., Mou Y. K., Lin Z. W., Sun H. D., Chem. Pharm. Bull., 7, 790-793 (2003).

7) Han Q. B., Zhang J. X., Zhao A. H., Sun H. D., Lu Y., Wu Y. S., Zheng Q. T., Tetrahedron, 60, 2373-2377 (2004).

8) Han Q. B., Lu Y., Zhang L. L., Zheng Q. T., Sun H. D., Tetrahedron Lett., 45, 2833-2837 (2004).

9) Han Q. B., Zhao A. H., Zhang J. X., Lu Y., Wu Y. S., Zheng Q. T., Sun H. D., J. Nat. Prod., 66, 1391-1394 (2003).

10) Huang S. X., Xiao W. L., W. L., Li L. M., Li S. H., Zhou Y., Ding L. S., Lou L. G., Sun H. D., Org. Lett., 8, 1157-1160 (2006).

11) Li L. M., Li G. Y., Ding L. S., Lei C., Yang L. B., Zhao Y., Weng Z. Y., Li S. H., Huang S. X., Xiao W. L., Han Q. B., Sun H. D., Tetrahedron Lett., 48, 9100-9103 (2007).

12) Li J. C., Liu C. J., An X. Z., Sun H. D., Lin Z. W., Acta Bot. Yunnanica, 4, 453 (1984).

13) Yang L. B., Yang J., Li L. M., Lei C., Zhao Y., Huang S. X., Xiao W. L., Han Q. B., Pu J. X., Sun H. D., Tetrahedron Lett., 49, 3574-3577 
(2008).

14) Fujita E., Fujita T., Shibuya M., Tetrahedron Lett., 1977, 3153 (1977).

15) Zhang J. X., Chen Z. Y., Wang Y. X., Qiu P. Y., Huang S. X., Sun H. D., J. Chem. Res., 7, 420-421 (2006).

16) Takeda Y., Ichihara T., Takaishi Y., Fujita T., Shingu T., Kusano G., J. Chem. Soc., Perkin Trans. 1, 1987, 2430 (1987).

17) Zhao Q. Z., Chao J. H., Wang H. Q., Sun H. D., Zhongcaoyao, 2, 49 (1984).

18) Sun H. D., Lin Z. W., Niu F. D., Lin L. Z., Chai H. B., Pezzuto J. M., Cordell G. A., J. Nat. Prod. 10, 1424 (1994).
19) Takeda Y., Fujita T., Chen C. C., Chem. Lett., 1982, 833 (1982)

20) Fujita E., Fujita T., Taoka M., Katayama H., Shibuya M., Chem. Pharm. Bull., 6, 1357 (1973).

21) Fukushima I., Sayama Y., Kyogoku K., Murayama H., Agric. Biol. Chem., 9, 1103-1107 (1968).

22) Fujita E., Nagao Y., Node M., Kaneko K., Nakazawa S., Kuroda H., Experimentia, 32, 203 (1976).

23) Mosmann T., J. Immunol. Methods, 65, 55-63 (1983).

24) Reed L. J., Muench H., Am. J. Hyg., 27, 493-497 (1938). 